\title{
Method to Foster Sense of Community among Students in K-12 Online Education
}

\author{
Ling Li
}

\author{
School of International Studies, Zhejiang University, Hangzhou, Zhejiang Province, China
}

Keywords: K-12 online education; sense of community; synchronous; games

\begin{abstract}
K-12 education is of great significance in students' growth, not only because it provides knowledge to children, but also in that it equips them with necessary interpersonal skills and affectivity, without which, education can at most be called training. Online education is booming around the world, but data obtained from Australia's schools of K-12 online education indicates the lack of sense of community nurturance among students. Based on the framework of role assignment and "engagement theory", synchronous lessons for role-playing and subject-related gamesis recommended.In order to avoid overloading the teachers in online education, volunteer supervisors for these synchronous lessons can be picked from caring parents.
\end{abstract}

\section{Introduction}

Online education is coined, improved and expected to grow prosperously. Nowadays, most of the lessons it providesare asynchronous, which not only help learners overcome the constraints of time and location, but also allowthem to study at their own pace(Richardson \& Swan, 2003; Simonson et al., 2009). Some researches also proved that distance education, which is almost the synonym for online education now,can offercrucial educational and social supportto parents homeschooling their children (McDonald \& Lopes, 2014). Besides, in terms of academic achievement, no significant differences have been found between online education and school-based education (Falck et al., 1997; Ryan, 1996; Smith, Clark \&Blomeyer, 2005).

However, without face-to-face interaction with teachers and peers, students may feel isolated(Hara \& Kling, 2000; Liu et al., 2007; Rovai\&Wighting, 2005). Natale et al. (2015) straightly stated that although students can review learning materials repeatedly to reach full understanding in online education, without human mediation, it is training not education. Natale\&Libertella (2016) further explained six shortcomings of online education, a half of which are related to interaction among students. Moore et al (2012) also pointed out that students' feeling of frustration and anxiety would increase when they hold certain misconceptions like 24-hour access to teachers. These may all lead to high levels of dropout in online courses (Stover, 2005; Glass \&Welner, 2011).Thus, establishing students' sense of community is strongly recommended (Liu et al., 2007; Rovai\&Wighting, 2005), which can not only decrease students' anxiety and loneliness but also improve their interpersonal skills and empathy for others. Methods like assigning roles to students have been put forward in higher online education (Hara et al., 2000), which inspires more peer interaction, encourages students to shoulder certain responsibilities and helps them to obtain better understanding of the learning materials. Jiang (2017) claimed that most students participate passively in the role-assigned discussion, only to satisfy the minimum requirement of a course. If it is hard to organize students in higher education to do such kind of work, it would be almost impossible forstudents in k-12 online education to participate actively and independently in their asynchronous activities even with role assignment. 
Although the significance of sense of community nurturance is obvious, few related studies have been conducted in terms of k-12 online education. The methods or theories employed in higher online education may not be applicable at the K-12 level. Furthermore, while higher education is optional, k-12 education in many countries is compulsory, making it more urgent to conduct some researches or design certain methods to scaffold young students' sense of community in k-12 online education. This paper firstly analyses data from schools of distance education in Australia, where young children living in rural areas or with special needs rely heavily on distance education; then, based on engagement theory, methods are proposed to foster students' sense of community in online education.

\section{Sense of Community nurturance in Australian K-12 distance education}

Australia's vast territory and scattered population push it into a country with advanced distance education. Schools of the air were first invented to provide education to children in remote Australia. Radio used to be the main media, but recently it has been replaced by internet technology. Other schools of distance education in Australia also rely on the internet. Thus, distance education in Australia can be generalized as online education, except the fact that distance education also involves certain face-to-face interaction between teachers and students.

At present, Australia has 10 schools of the air and 19 schools of distance education, all of which provide extracurricular activities, like camps, school tours to promote the interrelationship among students, since most of their lessons are asynchronous. Detailed information is showed in Table 1.

\begin{tabular}{l|c}
\hline \multicolumn{1}{c|}{ School } & $\begin{array}{c}\text { Number of annual } \\
\text { extracurricular activities }\end{array}$ \\
\hline Kalgoorlie School of the Air & 4 \\
\hline Alice Springs School of the Air & 5 \\
\hline Carnarvon School of the Air & Not found \\
\hline Katherine School of the Air & 2 \\
\hline Kimberley School of the Air & Not found \\
\hline Meekatharra School of the Air & 2 \\
\hline Mount Isa School of the Air & 5 \\
\hline Open Access College & 5 \\
\hline Port Hedland School of the Air & 5 \\
\hline School of the Air & 3 \\
\hline Bourke Walgett School of Distance Education & 4 \\
\hline Brisbane School of Distance Education & 7 \\
\hline Cairns School of Distance Education & 5 \\
\hline Capricornia School of Distance Education & 7 \\
\hline Charleville School of Distance Education & 3 \\
\hline Charters Towers School of Distance Education & 10 \\
\hline Distance Education Centre Victoria & 1 \\
\hline Dubbo School of Distance Education & 5 \\
\hline Longreach School of Distance Education & Not found \\
\hline North East Public School of Distance Education & 4 \\
\hline Northern Territory School of Distance Education & \\
\hline
\end{tabular}




\begin{tabular}{l|c}
\hline Schools of Isolated and Distance Education & 1 \\
\hline Sydney Distance Education High School & 7 \\
\hline Sydney Distance Education Primary School & Not found \\
\hline Riverside Christian College & 7 \\
\hline Groves Christian College & 2 \\
\hline ACC Moreton & 9 \\
\hline ACC Marsden Park & Not found \\
\hline ACC Albany & Not found \\
\hline
\end{tabular}

Table 1: Numbers of Co-curricular Activities in Australian Online Education

(Data is collected from the schools' websites and their annual reports.)

Related information of six schools in table 1 could not be found online. From the statistics obtained, we know the average number of annual extracurricular activities in Australian k-12 online education is only 4.61.Besides, although certain schools like Distance Education Centre Victoria organize many activities for students, most of the activities last only for a day or for a few hours, which means the total amount of time those students spend together is still too little and they can easily feel isolated in their daily online learning. Furthermore, due to the consideration of expense, time or students' special needs, parents may choose not to send their kids to these optional activities, which adds difficultyto facilitate intercommunication and social contacts among the students. Therefore, it can be concluded that Australia's k-12 online education severely lacks the nurturance of students' sense of community.

\section{Methods to promote sense of community}

Extracurricular activities can never be compulsory, increasing the uncertainty of students' sense of community nurturance. Education should be different from skill training, so methods need to be invented for curricular lessons. In the field of technology-based education, "Engagement theory" reminds people that authentic learning can be achieved more easily under project-based engagement and meaningful interactions (Kearsley\&Shneiderman, 1998). Thus, more fascinating online projects need to be inserted into those curricular lessons. Though role assignment tasks applied in higher online education may not be suitable for k-12 distance education, they are quite inspiring.

1. Synchronous lessons for games

Students can be better involved when assigned roles in a learning project. However, even students in higher online education may fail to participate actively in those asynchronous role-assigning tasks. According to Jiang (2017), students finishing their part early in a week might miss all the discussion posted later, in that they could beunwilling to browse the forum after the completion of their own task. Thus, it may work better if the role-assigning projects are in synchronous lessons instead of asynchronous ones.

As for students at the level of K-12, if students'keen interest is aroused, stronger motivation, more active participationand more intimate interrelationship are excepted to occur. Digital games have been proved to be useful in the field of education. Gros (2007) pointed out the benefits of digital games as user-oriented, challenging-promoting, cooperation-fostering and strategies-developing. Thus, digital games with different roles may be employed in the synchronous lessons. Students can switch roles each week to get a full understanding of the whole learning program. Creating digital games based on the learning materials may be time-consuming but profound and meaningful in the long run. Some educational games like Kahoot! can also be adopted 
in K-12 online education and different roles assigned to students can be teamleaders, members and supervisor's assistants, etc.

On the one hand, weekly synchronous games for each subject is recommended to scaffold students' sense of community; on the other hand, online education's high efficiency and great convenience is usually based on the sacrifice of the teachers' time and energy. To balance the contradiction between teachers' limited time and energy and students' urgent need for supervision over their weekly synchronous lessons for different subjects, responsible and caring parents may be picked as volunteers to manage the virtual classroom. They can send feedbacks to teachers each week, which will help teachers to make adjustment to the arrangement of the synchronous lessons. Besides, the frequent communication between parents and teachers can also improve the quality of students' online education.

\section{Conclusion}

Australia's online education is relatively advanced around the world. However, the data obtained indicates that schools offering K-12 online education fail to provide enough chances for students to build their sense of community, which is indispensable in the process of one's growing up. Thus, more compulsory lessons in curricular should be inserted with programs fostering students' interaction and communication. This paper, based on "engagement theory", puts forward a new method to get students fully involved and attracted by the programs. Digital games with role assignment can theoretically increase students' engagement and comprehensionof the learning materials, which will finally lead to strong sense of community. More empirical researches are needed to testify this new method in the future.

\section{References}

Falck, A-K; Husu, J; Kronlund, T., Kynaslahti, H. Salminen, J., \&Salonen, M. 1997. Testing virtual classroom in the school context [J]. Distance Education 18:213.

Glass, G. V., \&Welner, K. G. 2011. Online K-12 Schooling in the US: Uncertain Private Ventures in Need of Regulation. Boulder, CO: National Education Policy Center.

Gros, B. 2007. Digital games in education: the design of games-based learning environments [J]. Journal of Research on Technology in Education 40(1): 23-38.

Hara, N., Bonk, C. J., \&Angeli, C. 2000. Content analysis of online discussions in an applied educational psychology course[J]. Instructional Science 28: 115-152.

Jiang, W. 2017 Interdependence of roles, role rotation, and sense of community in an online course [J]. Distance Education 38: 84-105.

Kearsley, G., \&Shneiderman, B. 1998. Engagement theory: a framework for technology-based teaching and learning[J].Educational Technology38:20-23.

Liu, X.,Magjuka, R., Bonk, C., \& Lee, S. 2007. Does sense of community matter? Anexamination of participats' perceptions of building learning communities in online courses [J]. Quarterly Review of Distance Education 8: 9-24.

McDonald, J., Lopes, E. 2014. How parents home educate their children with an autism spectrum disorder with the support of the schools of isolated and distance 
[J]. International Journal of Inclusive Eductaion 18(1): 1-17.

Moore, J. L., Dickson-Deane. C., Galyen., Kumalasari, C. \& Kwon, K.2012. The ZONE learning community: gaining knowledge through mentoring [J]. First

Monday 17:9-3.

Natale, S. M., Libertella, A. F. \& Doran, C. J. 2015. For-profit education: the sleep of ethical reason [J]. Journal of Business Ethics 126: 415-421.

Natale, S. M., \&Libertella, A. F. 2016. Online education: values dilemma in business and the search for empathic engagement. 138: 175-184.

Richardson, J. C., \& Swan, K. 2003. Examining social presence in online course in relation to students’ perceived learning and satisfaction [J]. Journal of Asynchronous Learning Network 7: 68-88.

Rovai, A. P., \&Wighting, M. J. 2005. Feelings of alienation and community among higher education students in a virtual classroom [J]. The Internet and Higher

Education 8: 97-110.

Ryan, W. 1996. The effectiveness of traditional vs. audiographics delivery in senior high advanced mathematics course [J].Journal of distance Education11:2.

Simonson, S., Smaldino, S., Albright, M., \&Zvacek, S. 2009. Teaching and Learning at A Distance: Foundations of Distance Education [M]. Boston, MA: Allyn \&

Bacon/Pearson.

Smith, R., Clark, T., \&Blomeyer, R. L. 2005. A Synthesis of New Research on K-12 Online Learning. Naperville, IL: Learning Point Associates.

Stover, C. 2005. Measuring-and understanding-student retention [J]. Distance Education Report 9(16): 1-7. 